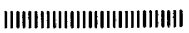

論 文

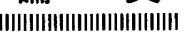

\title{
本縫ミシンにおける上糸張力と上糸移動量の同時計測法
}

\author{
鎌田 佳伸*, 加藤 豊文**, 小田 拓也*** \\ 坂本 勝之 ${ }^{* * *}$, 安藤 幸広 ${ }^{* * * *}$, 稲田 雅巳****
}

\section{Simultaneous Measuring Method of Needle Thread Tension and Needle Thread Movement for Lockstitch Sewing Machine}

\author{
Yoshinobu Kamata*, Toyofumi Kato**, Takuya Oda*** \\ Katsuyuki Sakamoto ${ }^{* * * *}$, Yukihiro Ando****, Masami Inada****
}

\begin{abstract}
Understanding of general mechanism of the needle thread tension and the movement of the needle thread drawn out of the tension disc during a stitch formation is indispensable for performance of an excellent sewing. We propose a new simultaneous measuring method of them in high speed sewing with an industrial singleneedle lockstitch sewing machine. Two detectors for measuring needle thread tension were installed between the left arm thread guard and the needle bar connecting the stud thread guard, and between the right arm thread guard and the bending thread guard, respectively. The needle thread tensions are detected by sensing the deflection of a cantilever beam using semi-conductor strain gages. A laser feed monitor, manufacturing by Keyence Co., Ltd., model FC-2000 was used for measuring needle thread movement. The sensor head was installed on the sewing machine being out of contact with the machine. Needle thread movement was measured by using a rotating ring which moved with the needle thread because it was impossible to measure the thread movement directly. The ring and the ring holder are made of acrylic plates. Silicon oil is slightly supplied between them to reduce frictional force. The ring has $20 \mathrm{~mm}$ in outer diameter and only $0.1 \mathrm{~g}$ of weight, so it seems to be possible to neglect inertia force of the ring. The tension waves and the movement wave are recorded simultaneously with the marker signals generated at the upper dead point of the needle bar.
\end{abstract}

(Received Oct. 7, 1997)

(Accepted for Publication Jan. 14, 1998)

\section{1.はじめに}

一般に，ミシンは 2 枚以上の布を縫系をむって繫 ぎ合わせる機械である。しかし，単に繫ぎ合わせれ ば良いかというと，そうではなく，繫ぎ目（縫目） のきれいさが商品価值から要求される. 高速でミシ ンを稼働させると低速でミシンを稼働させた場合に 比して縫目のきれいさが損なわれる傾向にある。そ れゆえ, 工業用本縫いミシンは毎分5000針程度の高
速で稼働するすのが製造されているにあかかわら ず，実際の縫製作業ではそれよりかなり低い速度で 使用されている現状にある.

縫製作業において，上糸は一針ごとに順次縫い込 まれてゆく，そのために天秤の引き上げ時に上糸量 が不足するので, 上糸張力が発生する. そして, そ の張力によって下系を布中に引き上げ，縫目を締 め, そして糸調子皿から新たな上糸を引き込む（こ の引き込む上糸量を上糸移動量と呼ぶ)。 そしてさ

*会員, Member, 香川大学教育学部, Faculty of Education, Kagawa University，高松市幸町, Saiwaicho, Takamatsu, Kagawa,

**会員, Member, 東京農工大学工学部, Faculty of Technology, Tokyo University of Agriculture and Technology, 小金井市中 町, Nakacho, Koganei, Tokyo, ${ }^{* * *}$ 東京農工大学工学部, Faculty of Technology, Tokyo University of Agriculture and Technology，小金井市中町, Nakacho, Koganei, Tokyo, ${ }^{* * * *}$ アイシン精機(侏), Aisin Seiki Co., Ltd., 刈谷市朝日町, Asahi-machi, Kariya, Aichi 
らに送り作用によって上糸と下糸の交絡点の布中の 位置が決まる。これらの過程において，その上糸移 動量の安定していることが均質で良好な縫目形成に とって大切なことはいうまであない.しかし，縫糸 消費量（被縫製布の 1 針ごとの縫糸量）の測定 ${ }^{1)}$ は, 連続する縫糸消費量は不規則に変動していると 報告されているし, 我々の予備的調査であ同様な結 果を得ている. しかし，その変動の発生原因につい てはわかっていない，また，その対策も見出されて はいない，我々は，その原因究明のためには少なく とも上系に発生する張力と移動量との関係を調べる ことが必要であろうと考える．前に写真技術を用い て上糸移動量を測定し，かま抜け時に発生する特別 大きな上糸張力が上糸移動を発生させている事実を 明らかにした ${ }^{2,3)}$. しかし，この場合には，ミシン 1 回転中の固定されたある区間内の移動量を調べるに とどまったため, 上糸張力と上糸移動量の詳細な対 応関係を知るには至らなかった。

従来から，上糸の張力測定に関するいくつかの報 告(4) はる. 上糸の移動量の計測に関しては, 上記の 文献 3）以外の報告には回転角度計を用いた報告5,6) はあるが, 検出器である回転角度計の慣性力の影響 を考慮するとごく低速しか適用できないむのと考え られる。なお，実用性が期待されるものとしてレー ザドップラー流速計の利用が考えられるが，その報 告例は見られない. 我々は, レーザドップラー流速 計に比して $1 / 10$ 程度の費用で利用できる，すなわ ち, 比較的安価であるレーザフィードモニタ（レー ザ測長・スピード計，キーエンス製）を利用した上 糸移動量の測定方法を考案した. その結果, 上糸張 力と上糸移動量の連続同時計測が可能なシステムを 構築することができた。本報告では，その構築した 上糸張力と上糸移動量の同時計測システムについて 報告する。

なお，本報で用いる用語「上糸張力」と「上系移 動量」について明確化しておく. 上糸張力とは, 稼 働中の上糸に発生する張力であり, その值は測定場 所により異なる. 上糸張力の中で, 特に, 天秤上死 点付近で発生する張力波形のピーク值は, 布締め時 の張力であるので, 引締張力と呼び, 上糸がかま止 め部之内がま押さえの爪を抜けるときに発生する張 力のピーク值をかま抜け張力，そして上糸がかまの 最下端を通過する時に発生する張力のピーク值をか ま越し張力と呼ぶ。上糸移動量とは, 系調子血から 縫目形成側へ引き入れられる上糸量である. 特に,
ミシン 1 サイクルの上糸移動量を総上糸移動量, 布 締め時を引締上糸移動量，かま抜け時をかま抜け上 糸移動量，そしてかま越し時をかま越し上糸移動量 之呼ぶ。なお，上糸移動量はミシン稼働中に 1 針ご とに糸調子皿から引き入れられる上糸量であり，被 縫布に存在する上糸消費量の個々とは必ずしも一致 するとは限らないが, 平均值としては対応するはず である.

\section{2. 測定方法}

\section{1 上糸張力の測定法}

上糸張力の測定には, 半導体ひずみゲージをセン サとするカンチレバー方式を用いた，測定位置は天 秤と針の間および天秤と糸調子皿の間の 2 か所であ り, 前者で測定される張力を $\mathrm{Ta}$ と呼び, 後者を $\mathrm{Tb}$ 之呼ぶ（図 1). 張力 Ta は縫目形成に直結する張力 で, 張力 $\mathrm{Tb}$ は糸調子皿における上糸の把持に関す る情報を与える張力である. なお， ミシンと張力検 出器との間に防振ゴムを挟み, ミシンの振動による ノイズ対策を行った．また，電気的なノイズ対策と してメモライザに取り込まれるまでの配線に高周波 シールドを施した. 本張力検出器の固有振動数は,

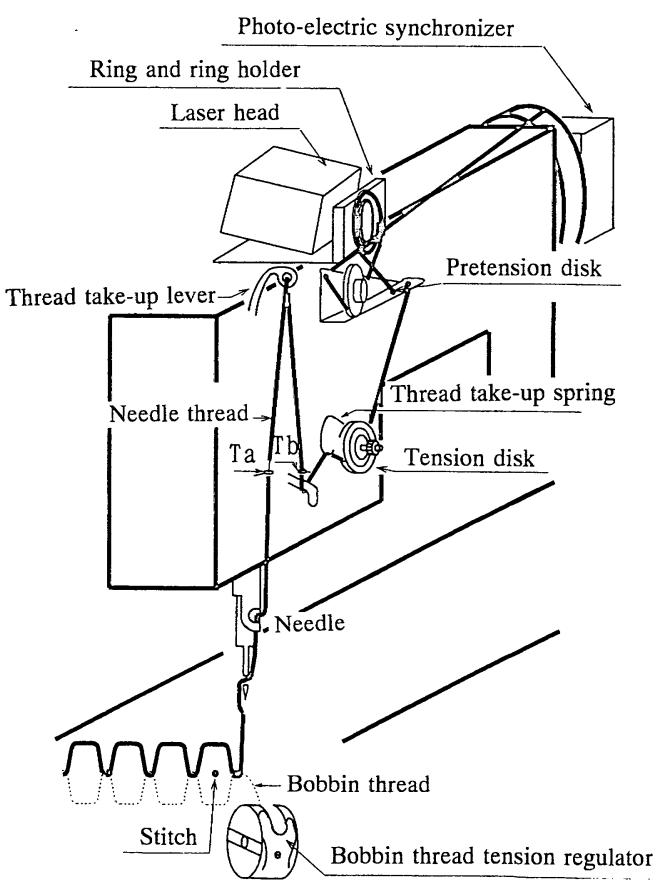

Fig. 1 Install of needle thread tension detectors and the needle thread movement detector 

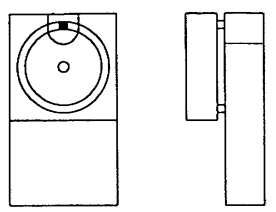

Laser head

2-1 Assembly diagram of the needle thread movement detector

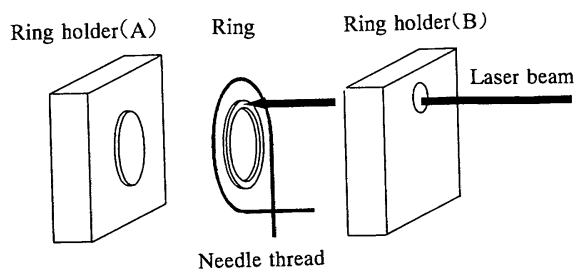

2-2 Ring and ring holders

Fig. 2 Detail of Needle thread movement detector

Ta で $15,600 \mathrm{~Hz}, \mathrm{~Tb}$ で $8,100 \mathrm{~Hz}$ であった. 追従周波 数を固有振動数の 3 分の 1 と考えると, $3,600 \mathrm{spm}$ 回転のミシンにおいては，Taでおよそ 4 度， $\mathrm{Tb}$ で およそ 8 度である。これより低速の場合には速度に 比例して追従周波数は小さくなる.

\section{2 上糸移動量の測定法}

本報告の主体は上糸移動量の計測法にあるので, その方法について次に詳細に述べる。

\subsection{1 上糸移動量の測定代替器}

上糸の移動量の検出に上糸の移動（走行）の代替 として回転リングを利用した。 その構造を図 2 に示 す. 図 2-1 は組付図で, 図 2-2にリングとリング受 けの分解図を示した. リングの外径は $20.7 \mathrm{~mm}$, 内 径は20.4mm, 幅は $1.25 \mathrm{~mm}$, 重量は0.11g である. リングとリング受け（A）は透明アクリル製，リン グ受け（B）のみはテフロン製である.リングの回転 摩擦の増加は上糸張力の増大につながるため, 張力 測定に影響を与える。 そのため，加工面を研磨し， 可能な限り回転抵抗の低減に努めた。ただし, 測定 用レーザ光の通過防止のためリングの片面は塗料で 着色した後に研磨してある. リングとリング受け （A）の潤滑にはシリコンオイルを使用した。 また， リングの回転慣性力を抑えるために極力軽量化をは かった。これらの処置により，かま抜け移動などの
微小移動にあ対応することができるすのとなってい る.なお, リングの外周には幅 $0.5 \mathrm{~mm}$, 深さ $0.5 \mathrm{~mm}$ の V 字型の糸の走行溝が掘られている.

\section{2 .2 リングの回転検出}

上糸の移動を代替するリングの回転検出にはレー ザフィードモニタ（㑣)キーエンス製, 型名：FC2000）を用いた。 その測定原理はレーザ光の反射イ メージを CCD 素子で取り込み, そのイメージが次 のサンプリング時までに移動した位置との比較か ら, サンプルの移動距離を計測するものである. 光 源には波長 $780 \mathrm{~nm}$ の半導体レーザが用いられてい る. その仕様性能は, 照射距離 5 40mm の範囲で, 移動速度 $4 \mathrm{~m} / \mathrm{s}$ までの対象物を，移動距離に対して $\pm 0.5 \%$ 精度で測定することができるとされている.

\subsection{3 上糸移動量測定器の設置}

上糸移動量測定器は, 上糸移動量の測定代替器と レーザフィードモニ夕とで構成される（図 2-1）。 そ のミシンへの設置状態は図 1 に示されている，プリ テンションに取り込まれた上糸はリングに導かれ， リングの外溝を一周巻き付かされた後, またプリテ ンションに戻される，糸の移動はリング側面の動き で代替される，なお，レーザ光のへッドはリング側 面に対して約 6 度の傾きを持って取り付けてある. レーザフィードモニ夕は直線移動を測るものである ため，本実験のように回転体側面の移動を測定する には厳密な意味では適していない，偶然ではある が，レーザヘッドの取り付け角によって測定結果が 変わることを知り，それを利用したキャリブレーシ ョンを行った。 すなわち，一定速度で回転するモー 夕で上糸を卷き取り，モニターの示す速度とモータ の周速とが一致するようにレーザ光の角度を調節し た. 角度の調整ありとなしの 2 種類のキャリブレー ションの結果を図 3 に示す.

\section{3 上糸張力と上糸移動量の同時測定システ ム}

\subsection{1 計測システムの構成}

計測システムの構成を図 4 に, 使用機器の一覧を 表 1 に示す. 上糸張力測定器は防振ゴムを介してミ シンに固定されているが, 上糸移動量測定器はミシ ンに接触していない。レーザ照射ヘッドで検出され た上糸移動量データはアンプユニットの内部で処理 され，アナログ変換機に送られる，そこでアナログ 電圧に変換された後，メモライザに取り込まれる. 上糸張力 $\mathrm{Ta}$ 值と $\mathrm{Tb}$ 值もメモライザ内蔵のひずみ 


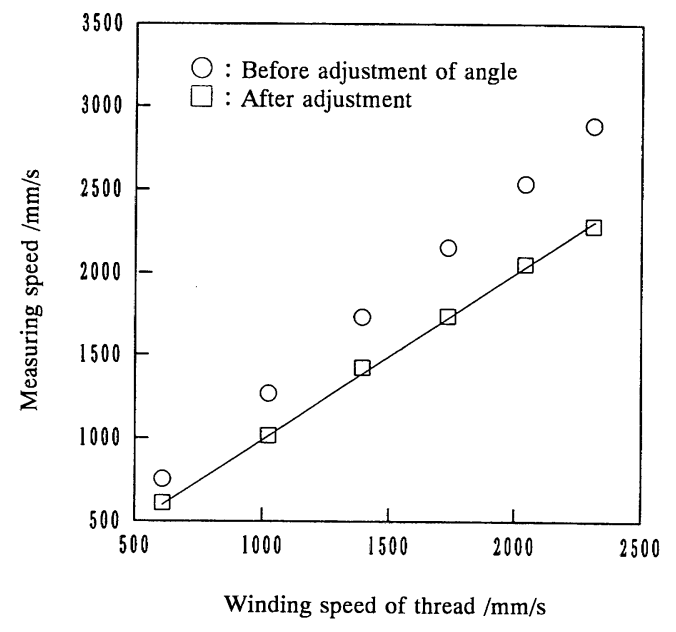

Fig. 3 Calibration curve

Table 1 measuring instrument

\begin{tabular}{lcl}
\hline Photo-electric synchronizer & PS-1A & Sugawara Laboratory Co., Ltd. \\
Stroboscope & PS-240 & \\
Lamp house & PL-240 & \\
Memorizer & $7 G 01$ & NEC San-ei Instruments, Ltd. \\
Laser feed monitor & FC-2000 & Keyence Co., Ltd. \\
Analog pulse unit & FC-500 & \\
\hline
\end{tabular}

変換器を通してメモライザに取り込まれる．また， メモライザには同時に上軸回転角度信号（マーカ信 号）が取り込まれる. マーカ信号は, 光学式シンク ロナイザのトリガにより針棒上死点の上軸回転角度

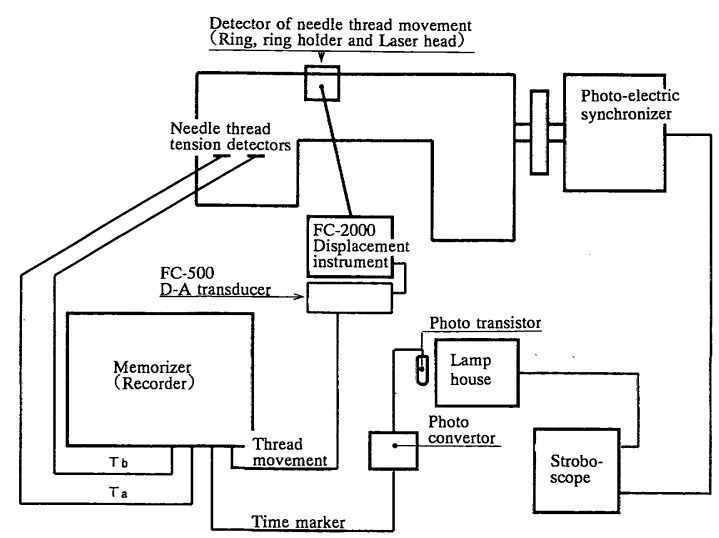

Fig. 4 Measuring system
で発光するストロボスコープのランプハウス前に取 り付けられたフォトトランジスタに誘起する電圧信 号である。なお，マーカ信号の発生にストロボスコ 一ブを用いた埋由は, 本研究では使用していない が，任意の上軸回転角度でストロボスコープを発光 させ，それにスチールカメラを連動させて高速で動 く糸の挙動の観察等を行うことができるシステム構 成とするためである，メモライザに取り込まれた上 糸張力と上糸移動量のデータは, マーカ信号により 角度に対応した張力波形として処理される. 使用し たメモライザは $1 \mathrm{ch}$ 当たりのメモリが $16 \mathrm{kw}$ であっ た. 本研究では, 上軸回転角の約 1 度ごとに, すな わち, 1 縫目当たりおよそ 360 デー夕を採取すること とした.この結果, $44(\fallingdotseq 16000 / 360)$ 縫目数程度の 連続測定ができる.

\subsection{2 デー夕処理}

メモライザに取り込まれたデータはフロッピーデ イスクに落とされ, 本研究用に作成した処理プログ ラムを用いてパソコンにより処理される. その処理 内容は, 次に述べる上糸移動量データの位相補正や マーカ信号を用いた自動分割, さらに, 要求による 波形の拡大・縮小表示やピーク值の自動切り出し等 ができる.

1) 上糸移動量データの位相補正

レーザ照射ヘッドから検出された上糸の移動量の データは変位測定器（レーザフィードモニタ FC2000) と D-A 変換器（アナログパルスユニット FC-500）を経てメモライザに取り込まれる.メーカ 一の説明によると, (1)FC-2000内部でのデータサン プリングが $0.1 \mathrm{~ms}$ でなされているので, この過程で 位相が遅れる. (2)データが FC-2000から FC-500へ RS-232Cにより送られる過程で $1.0 \mathrm{~ms}$ 位相が遅れ る. さらに, (3)FC-500内でアナログ電圧に変換する ときに $0.2 \mathrm{~ms}$ 位相が遅れるとのことであった。した がって, 本システムではデータサンプリングでの位 相の遅れを平均して $0.05 \mathrm{~ms}$ として, 合計 $1.25 \mathrm{~ms}$ の 位相補正を行った.この位相補正では, データサン プリング時間において $\pm 0.05 \mathrm{~ms}$ の誤差が存在す る.この誤差はミシン速度が3600spm のと, 上軸回 転角でおよそ 1 度になる。

\section{3. 結果および考察}

\section{1 測定事例}

ミシン条件および被縫布と縫糸の条件は表 2 の通 
りである．糸調子血は，ミシン速度200spm で良好 な縫目バランス（上下系の縫糸長さが一致）となる ように設定した。この設定は，今後の研究における ミシン速度依存性の実験のために採用した条件であ る. 図 5-1 に毎分 3000 回転, 送り $3 \mathrm{~mm}$ の場合の連 続測定のデータ例を示す. 図の上部は上糸移動量 で, 下部はそれらに対応する上糸張力 $(\mathrm{Ta}, \mathrm{Tb})$ で ある。この図からは張力 $\mathrm{Ta}$ と $\mathrm{Tb}$ は重なっている ので両者の区別はつかない. 上糸移動量のデー夕は 上記のデー夕処理により針棒上死点で破断された 1 縫目ごとの上糸移動量で表示されている. 図から連 続した上糸移動量および上系張力が不規則に大きく 変動している様子が見て取れる。なお，張力波形に アンダーシュート張力が観察されるが，これはかま 抜け時の急激な張力の解放（内かま止め部に引っか かった上糸が解放される）で発生するあのであり，

2.1項で述べた本張力センサの追従周波数を越す速 さの張力変動が発生しているためによる. 図 5-2 は 図 5-1 の一部の拡大例である.この図では, 張力 $\mathrm{Ta}$ と $\mathrm{Tb}$ の違いや張力と上系移動との関係屯読み 取れる. また, 図 5-2 のデー夕とは異なるが, 張力 $\mathrm{Ta}$ と張力 $\mathrm{Tb}$ とを分離して上糸移動量とともに示 した例を図 6 に示す. 図の上段は張力 $\mathrm{Ta}$ と上糸移 動量で, 下段は張力 $\mathrm{Tb}$ と上糸移動量である. 両段 に示されている上糸移動量は同じあのである. 図中 に示した種々の上糸張力に対応して上糸の移動が発 生していることがわかる，A は引締張力，B はかま 抜け張力，C はかま越し張力であり，それらに対応 する上系移動がプライム符号で示されている. 本 来, ミシンは引締張力（A）の発生時においてのみ 糸調子血からの上糸の引き込み (A') が行われるの が理想であるが，実際にはその他の上糸張力によっ てあ引き出されている. 図では, かま抜け上糸移動 量が顕著であり，また，かま越し上糸移動量あごく 微少量ではあるが認められる。なお, 図では認めら れないが, 送り作用時（張力 D の発生時）にごくわ

\section{Table 2 Sewing conditions}

\footnotetext{
1. Sewing machine - SYSTEMA AD1100 (Aisin Seiki Co., Ltd.), industrial single -needle lockstitch sewing machine

Bobbin thread static tension: $20 \pm 2$ gf

Stroke of thread take-up spring: $10 \pm 1 \mathrm{~mm}$

Strength of thread take-up spring: $20 \pm 2 \mathrm{gf}$

2. Needle - DB $\times 1$ NO. 11

3. Sewn fabric $-T / C$ broadcloth ( 2 ply)

4. Sewing thread - No. 60 polyester spun
}

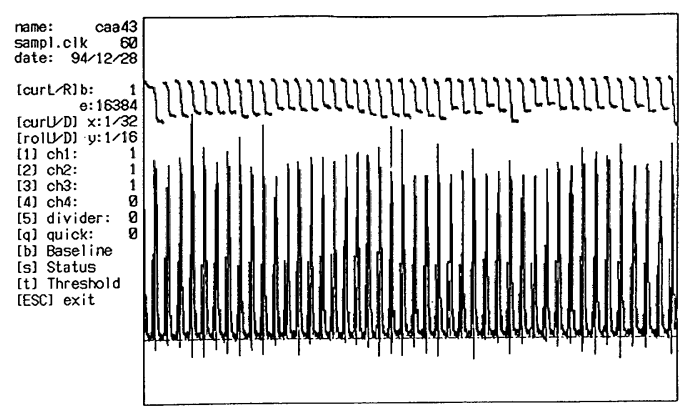

5-1 Continuous measurement

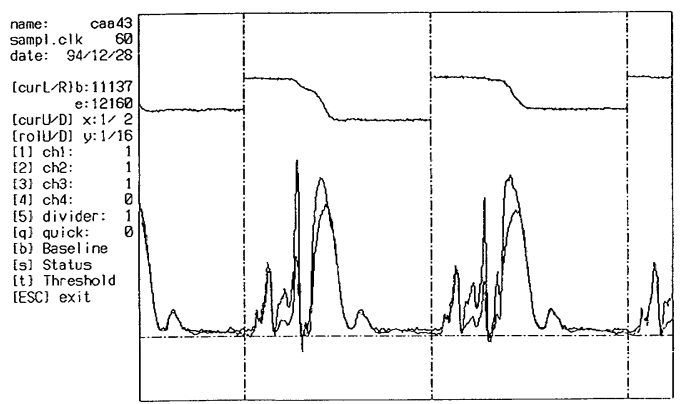

5-2 Zoom-up expression

Fig. 5 An example of simultaneous measurement of needle thread tensions and needle thread movement, (sewing speed is $3,000 \mathrm{spm}$ and feed length $3 \mathrm{~mm}$ )

ずかではあるが上糸移動の認められることあある.

図 5 と 6 から明らかなように, 連続した縫目につ いて上糸張力と上糸移動量の同時測定ができてい る. 現在のシステムではメモライザのメモリの制約 から連続測定は40針程度であるが，よりメモリ容量 の多い記録計を使うことでより多くの連続縫目の測 定が可能である.

\section{2 上糸移動量測定器の存在の影響}

上糸移動量測定器は縫糸の走行経路を大きく変え ている. その影響調查のために, 上糸移動量測定器 がある場合とない場合との張力波形の違いを調べ た. 図 7 に結果を示す。図加ら明らかなように両者 に差は認められ, 上糸移動量測定器を用いた方が若 干張力は高くなっているが，その違いはそう大きく ない. 移動量測定器のリングの回転抵抗が極めて小 さいことが確認され，また，その影響は問題にする ほどではないと判断した。 


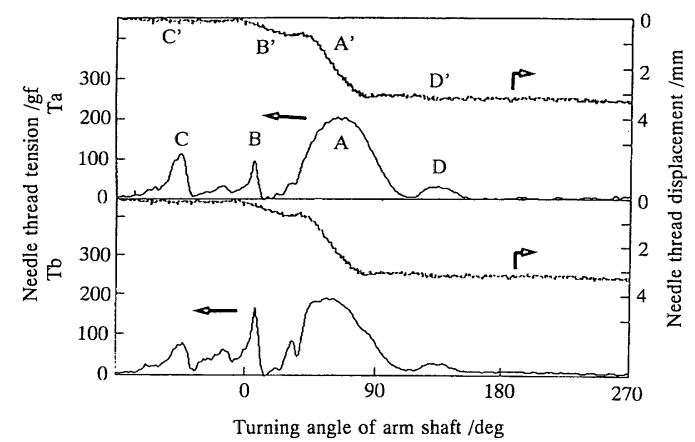

Fig. 6 An example of relationship between needle thread tensions, $\mathrm{Ta}$ and $\mathrm{Tb}$, and needle thread movement, (sewing speed is 3,000 spm and feed length $3 \mathrm{~mm}$ ) A : Needle thread tightening tension. A': Needle thread movement by the tension, A. B : Needle thread tension generated when the thread disengages from the rotating hook bobbin case holder position bracket and the rotating hook section jib. B': Needle thread movement part of the rotating hook. C': Needle thread movement by the tension, C. D : Needle thread tension with the feed motion. D': Needle thread movement by the tension, D.

\section{3 上糸移動量の計測器の追従性}

縫い速度が $3,000 \mathrm{spm}$, 送り長さが $3 \mathrm{~mm}$ の測定 例である図 6 において, 引締時の上糸移動はおよそ 44度で始まり84度で終了している。この間40度での 上糸の移動量が実測で $2.3 \mathrm{~mm}$ であるので, 上糸移 動速度は $1.04 \mathrm{~m} / \mathrm{s}$ 之計算される. また, 移動速度の 大きな計算例として, 本実験ミシンの最高速度 : $3600 \mathrm{spm}$, 上糸移動量 : $3.5 \mathrm{~mm}$, 上糸の移動角度範 囲：30度とすると, 上糸の移動速度は $2.54 \mathrm{~m} / \mathrm{s}$ とな る.レーザフィードモニタによる追従速度は $4 \mathrm{~m} / \mathrm{s}$ であるので, 例えば, かま抜け時に発生することが ある特別大きな張力による上糸の特異な移動がある とすれば，そのような移動を除いて，十分に測定結 果は信頼できるあのと考える.

\section{4. 結 言}

以上述べたように, 高速で稼㗢するミシンの上糸 移動量と上糸張力を同時測定するシステムを構築し

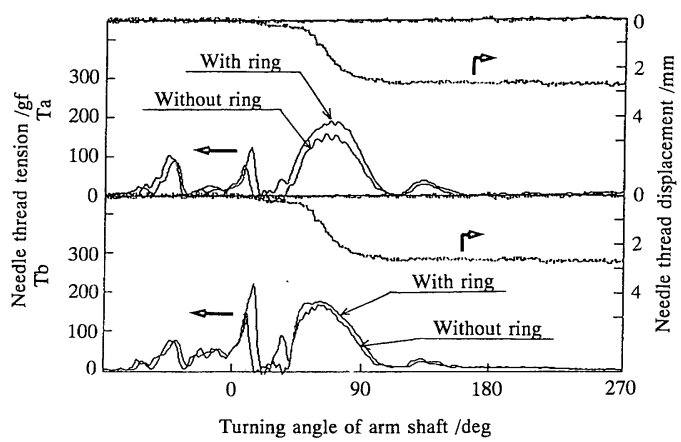

Fig. 7 Effect of being of the ring on needle thread tensions, (sewing speed is 3,000 spm and feed length $3 \mathrm{~mm}$ )

た.このシステムを用いれば稼働中の上糸の挙動に 関する詳細な情報が得られるものと期待される. 次 報では本縫いミシンの上糸張力と上糸移動量との関 係の詳細な調査結果を報告する.

なお，上糸移動量の測定法に関して次のことを申 し添えておく、レーザフィードモニタを用いた糸の 直接測定は, 糸の細さ, 表面粗さ等のため成功しな かった. また，上糸の走行を代替する方法として， 上糸と同時走行する反射テープの利用む検討した が，高速測定を条件とした時，テープの慣性力のた めに連続10針程度までが限界で，連続多量測定に適 さなかった。

\section{謝 辞}

本研究を遂行する上で重要なデー夕処理プログラ ムの作成に貢献頂いた, 東京農工大学大学院修士課 程 (当時) 廣田和彦君に深甚なる感謝を申し上げる。

\section{文 献}

1）岩神直, 安喰功; 繊維製品消費科学, 23，23（1982）

2）鎌田佳伸, 木下陸肥路, 石川昇之輔, 不二崎潔 ; 緎維機械 学会誌, 35, T60 (1982)

3）鎌田佳伸, 故木下陸肥路, 太田友忠 ; 緎維機械学会誌, 38, T171 (1985)

4）例えば, 宮下利平, 関口純一，笹原もと江，神立均；繊維 機械学会誌, 27, P55 (1974)

5）堀野恒雄, 三浦義人, 坂本勝之, 安藤幸広 ; 繊維機械学会 誌, 33, T7 (1980)

6) O. N. Gordeev and V.Pischikov Tech. Prom. No. 3,. 103 (1971) 